Theories \& Applications, the International Edition

Printed Version : (ISSN 2090-5262)

Online Version : (ISSN 2090-5270)

November 2014, Volume 4, No. 3 Pages (77 - 89)

\title{
The Impact of Using Functional Strength Exercises on Developing the Performance Level of Skill, FLOB 360, on a Pommel Horse Under the Age of 13.
}

\section{Dr. Haytham Abd El razzak Ahmed Dessoky}

Associated Professor, Department of exercises and gymnastics Faculty of Physical Education for Boys, Alexandria University, Egypt.

\section{Dr. Saqer Ghanim Abdulrazak Almullah}

Associated Professor, Department of physical and Sports education, the Public Authority for Applied Education and Training, College of Basic Education, Egypt.

\begin{abstract}
The research aims to try to identify the impact of using functional strength exercises on developing the performance level of skill, FLOB 360, on a pommel horse under the age of 13

The two researchers used the experimental method in a manner (pre-and post-tests) to two groups, one is experimental group and the other is control group .

The sample was chosen by the propulsive (intentional) method from the gymnasts in Kazma Sports Club and Kuwait club in Kuwait under the age of 13 for the sports season 2012/2013

The total sample size of the main research was (12) players trained together, and after the end of the training session they were divided into (6) players, as an experimental group, where the functional strength exercises were applied on them to a time period ranging between (15 to 20 minutes), and (6) players as a control group where the exercises were not applied on them .

The two researchers have used the tests and measurements of functional strength and the evaluation level of the skill's performance.

The results revealed that the use of functional strength exercises; improve the level of skill performance (FLOB 360) on the pommel horse.

The two researchers recommended applying the functional strength exercises the same intensity, repetitions and rests for gymnasts for its role in improving the level of skill performance (FLOB 360) on the pommel horse .
\end{abstract}

Key words: functional strength - (FLOB 360) skill -juniors.

\section{Introduction}

$\mathrm{G}$ ymnastics sport has lately achieved jumps in the performance representing in the ability of players to perform movements and elements that are characterized by high difficulties and at the same time lead to the aesthetic sense, and this of course requires from the gymnast to have some of the physical attributes and some technical and psychological abilities, which that requires from the player to spend a considerable period of time in training for developing these abilities, this evolution in skills performance necessarily is followed by the evolution of the different preparation programs for the player and it requires also to connect to the modern scientific methods. (21:79)

The development of muscular strength of the upper side of the body, especially the shoulders, arms, abdominal, back muscles and the strength of the fist, is the basic requirement in the physical preparation of the gymnast (22: 498).

This is reason is one of the reasons that pushed the Technical Committee of Men's Gymnastics in Kuwait to search about and to study the compulsory movements, the problems of these movements and the competition.
The pommel horse is one of the apparatus that has developed in recent years because of the new skills that have changed the shape and the nature of the performance on this apparatus.

The age under 13 years, where these compulsory movements, have appeared over the past years, were determined by the Technical Committee in the Kuwaiti Union of gymnastics including that the player perform (6) six movements with difficulty (A), (1) one movement with difficulty (B), (1) one movement with difficulty (D) (3).

on this basis, the player must perform the $\left(360^{\circ}\right.$ FLOPS) skill, as a part of the fourth group, which consists of Kimruonda , (360 ${ }^{\circ}$ FLOPS) movements and grasp movement and their difficulty in this case is (C) and but 360 ${ }^{\circ}$ FLOPS skill is the only skill which can be linked to pre and post skill so the difficulty raises to (D) (E), (F), (G) difficulties (33: 58) as detailed in the attachment (1).

The functional strength has many definitions so the two researchers collected those definitions and compiled them as described in the attachment (2).

The two researchers noted that the juniors don't have the required muscular strength to perform the $\left(360^{\circ}\right.$ FLOPS $)$ 
skill on the pommel horse with a high efficiency where it reflected clearly in the performance of juniors during the competition, also the two researchers noted that the coaches do not use sufficient exercises to develop the performance level of the FLOPS skill and the others skipped the importance of the functional strength exercises in the period of preparation, Although the functional strength exercises are performed as integrated movements with multi-levels (front , transverse, sagittal) including acceleration, grading and deceleration, in order to improve the motor ability, the central force (spine and the mid- body) and the neuromuscular efficiency $(30: 64)$

So the two researchers used the functional strength exercises to know the extent of their effect on the muscular strength on the Gymnastics juniors under 13 years and to know also the impact of the progress level of the $\left(360^{\circ}\right.$ FLOPS) skill on the pommel horse.

\section{Aims of the research :}

The research aims to design a training program using the functional strength and to know its impact on the performance level of the ( $360^{\circ}$ FLOPS) skill for the Gymnastics juniors under the age of 13 on the pommel horse.

\section{Research's hypotheses :}

- There are significant statistical variances between the pre and post measurements of the physical variables and the performance level of the $\left(360^{\circ}\right.$ FLOPS) skill for the Gymnastics juniors under the age of 13 on the pommel horse in favor of the control group and the post-measurement.

- There are significant statistical variances between the pre and post measurements of the physical variables and the performance level of the $\left(360^{\circ}\right.$ FLOPS) skill for the Gymnastics juniors under the age of 13 on the pommel horse in favor of the experimental group and the post-measurement.

- There are significant statistical variances between the control and experimental groups in the postmeasurement for each of the physical variables and the performance level of the ( $360^{\circ}$ FLOPS) skill for the Gymnastics juniors under the age of 13 on the pommel horse in favor of the experimental as a result of using the functional strength exercises on the pommel horse apparatus.

\section{Search procedures :}

1. Approach used : the two researchers have used the experimental approach (method) by using the experimental design with two groups, one is experimental and the other is control and by using also the pre and post- measurement for the two groups

\section{fields of research :}

space domain : All pre and post- measurements and the implementation of the training program's content were done at Kazma sports hall in Kuwait.

time domain : the two researchers executed the first pilot study on a sample similar to the study's sample, out of the main sample and from the same original research community, to:

- ensure from the validity of the apparatus, tools and from the suitability of the training program's exercise for the research's sample, that was on Saturday 5/1/2013 AD.

- The pre- measurements are executed from 8/1/2013 to $10 / 1 / 2013 \mathrm{AD}$.

- Applying and implementing the Research in the period from $12 / 1 / 2013$ to $11 / 4 / 2013 \mathrm{AD}$.

- The post- measurements are executed in the period from $13 / 4 / 2013$ to $15 / 4 / 2013$.

Sample Search : The sample was chosen by the propulsive (intentional) method from the gymnasts in Kazma Sports Club and Kuwait club in Kuwait under the age of 13 for the sports season 2012/2013, and the sample included (12) players divided into two equal and homogeneous groups , one is experimental and the other is control, each one is (6) six players, the same training program is applied except of the functional strength exercises that have been applied only on the experimental group.

Table (1)

Statistical description of data for the experimental, the control and the total group in the initial basic variables before the experiment

\begin{tabular}{|c|c|c|c|c|c|c|}
\hline \multirow[b]{2}{*}{ variables } & \multirow[b]{2}{*}{ groups } & \multirow[b]{2}{*}{ No. $\mathrm{N}$} & \multicolumn{4}{|c|}{ statistical semantics of the Description } \\
\hline & & & Arithmetic mean & median & $\begin{array}{l}\text { Standard } \\
\text { deviation }\end{array}$ & Coefficient of skewness \\
\hline \multirow{3}{*}{ Age to the nearest month } & Experimental & 6 & 12.567 & 12.55 & 0.216 & 0.463 \\
\hline & control & 6 & 12.448 & 12.4 & 0.139 & 1.395 \\
\hline & Total research groups & 12 & 12.508 & 12.45 & 0.184 & 0.920 \\
\hline \multirow{3}{*}{ Height CM } & Experimental & 6 & 40.907 & 40.895 & 1.071 & 0.596 \\
\hline & Control & 6 & 40.562 & 40.56 & 0.650 & $0.499-$ \\
\hline & Total research groups & 12 & 40.734 & 40.56 & 0.864 & 0.653 \\
\hline \multirow{3}{*}{ weight $\mathrm{Kg}$} & Experimental & 6 & 142.302 & 141.905 & 2.113 & 1.125 \\
\hline & control & 6 & 141.250 & 141.125 & 0.975 & 1.093 \\
\hline & Total research groups & 12 & 141.776 & 141.25 & 1.662 & 1.579 \\
\hline
\end{tabular}


It's Clear from Table 1 that the coefficients of skewness of the selected variables range between $(3 \pm)$, which demonstrates that the sample is distributed moderately

\section{Tools used:}

First: measurements:

- Rest Meter device to measure the height in $\mathrm{cm}$.

- Medical standard balance for measuring weight in $\mathrm{kg}$.

- Genomitr device to measure the expanding movement of the articular shoulders.

- Stop watch (1/100 seconds) to determine the testing time and the period of rest and training.

Secondly, the necessary tools for the implementation of the experiment: attachment (3).

Pommel horse with a legal height, low Pommel horse with rings, low Pommel horse without rings, mushroom apparatus with two rings, mushroom apparatus with one ring in the middle, mushroom apparatus, floor level mushroom apparatus, foam rings, mattresses, parallel bars ,wall bars, legal Pommel horse without rings, a shaving legal horse stretching out rings, ground mushroom nest.
Secondly, the physical tests and the assessment the performance level of (360 ${ }^{\circ}$ FLOPS) skill, attachment (4)

The nature of the research required choosing a set of physical and skill tests to assess the performance level of $\left(360^{\circ}\right.$ FLOPS) skill according to the validity of the tests and the ease of the implementation.

The scientific coefficients of the tests used:

\section{A. Coefficient of Validity}

The two researchers have used a discriminant method to find the validity of the tests. The two researchers applied the tests, under discussion; one of the two groups is the discriminant group that is the same used sample to find the reliability of the tests by using the same data of the first implementation and the Second group is not discriminant (juniors) from the same research community and out from the basic research sample with the same number of the first sample as shown in table (2).

Table ( 2)

Coefficient of validity for the physical tests and the performance level of the skill, under the study

\begin{tabular}{|c|c|c|c|c|c|c|c|c|c|c|}
\hline \multicolumn{3}{|c|}{ Statistical semantics } & \multirow[b]{2}{*}{ iables } & \multicolumn{2}{|c|}{ discriminant group $5=\mathrm{N}$} & \multicolumn{2}{|c|}{ Non-discriminant group $5=\mathrm{N}$} & \multirow{2}{*}{$\begin{array}{l}\text { difference } \\
\text { between } \\
\text { two means }\end{array}$} & \multirow{2}{*}{$\begin{array}{l}\text { Value } \\
(\mathrm{t})\end{array}$} & \multirow{2}{*}{$\begin{array}{l}\text { validity } \\
\text { coefficient }\end{array}$} \\
\hline & & & & mean & $\begin{array}{c}\text { Std. } \\
\text { deviation } \pm\end{array}$ & mean & $\begin{array}{c}\text { Std. } \\
\text { deviation } \pm\end{array}$ & & & \\
\hline \multirow{12}{*}{ 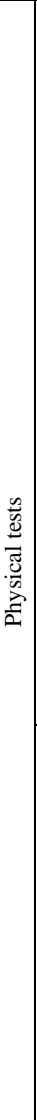 } & \multirow{7}{*}{ 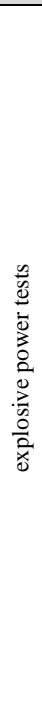 } & $\begin{array}{l}\text { Test of lifting up the hips highly } \\
\text { from the inverted grasp on the } \\
\text { jumping pommel horse during } \\
\qquad(15 \mathrm{~s})\end{array}$ & NO. & 11.443 & 0.709 & 8.704 & 0.262 & 2.739 & 12.555 & 0.976 \\
\hline & & $\begin{array}{l}\text { Test of lifting up the two legs to } \\
\text { touch wall bar with the two insteps } \\
\text { with the maximum number during } \\
(15 \mathrm{sec})\end{array}$ & NO. & 11.480 & 0.650 & 8.824 & 0.456 & 2.656 & 11.592 & 0.971 \\
\hline & & $\begin{array}{c}\text { Test of lifting up the two legs } \\
\text { backwardly to touch the tester's } \\
\text { hand when lying on the pommel } \\
\text { during }(15 \mathrm{sec})\end{array}$ & NO. & 15.633 & 0.650 & 11.369 & 0.400 & 4.264 & 19.354 & 0.989 \\
\hline & & $\begin{array}{l}\text { Test of lifting up the hips } \\
\text { forwardly, intersecting the two } \\
\text { hands behind the head, touching } \\
\text { tester's hand, lying on the pommel } \\
\text { horse during }(15 \mathrm{~S})\end{array}$ & NO. & 15.177 & 429. & 12.723 & 0.981 & 2.394 & 7.743 & 0.939 \\
\hline & & $\begin{array}{l}\text { Test of turning the Body from the } \\
\text { handstand position inside two } \\
\text { circles during }(15 \mathrm{~S})\end{array}$ & NO. & 11.710 & 0.724 & 7.667 & 0.488 & 4.033 & 16.005 & 0.985 \\
\hline & & $\begin{array}{l}\text { Test of stretching the two arms } \\
\text { when the chin is above the bar with } \\
\text { the maximum number during } 15 \mathrm{~S} \text { ) }\end{array}$ & NO. & 12.147 & 0.664 & 8.271 & 0.699 & 3.876 & 13.932 & 0980 \\
\hline & & $\begin{array}{c}\text { Test of stability and stalling on } \\
\text { pommel horse }\end{array}$ & $\sec$ & 30.910 & 4.208 & 14.377 & 0.299 & 16.533 & $\begin{array}{c}13.5777 \\
.331\end{array}$ & 0.979 \\
\hline & \multirow{5}{*}{ 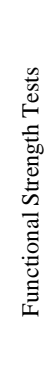 } & $\begin{array}{l}\text { Test of V-angular sitting position } \\
\text { on the parallel bars }\end{array}$ & $\sec$ & 10.367 & 2.381 & 4.858 & 1.051 & 5.528 & 7.331 & 0.933 \\
\hline & & $\begin{array}{l}\text { Test of handstand on the pommel } \\
\text { and stability on it }\end{array}$ & $\mathrm{sec}$ & 21.380 & 874. & 11.366 & 1.000 & 10.014 & 26.124 & 0.994 \\
\hline & & $\begin{array}{l}\text { Test of the inverted hung (grasp) on } \\
\text { the pommel and stability in } \\
\text { backward position }\end{array}$ & $\mathrm{sec}$ & 10.380 & 1.029 & 4.683 & 1.068 & 5.698 & 13.314 & 0.978 \\
\hline & & $\begin{array}{l}\text { Test of the inverted hung (grasp) on } \\
\text { the pommel and stability in forward } \\
\text { position }\end{array}$ & $\mathrm{sec}$ & 5.250 & 0.789 & 1.788 & 0.396 & 3.463 & 12.591 & 0.979 \\
\hline & & $\begin{array}{l}\text { Test of planch, with opening legs } \\
\text { from behind, on the parallel bars } \\
\text { from the angular leaning position }\end{array}$ & NO. & 8.240 & 0.849 & 3.663 & 0.895 & 4.578 & 12.852 & 0.977 \\
\hline
\end{tabular}




\begin{tabular}{|c|c|c|c|c|c|c|c|c|c|}
\hline \multirow{2}{*}{\multicolumn{3}{|c|}{ Statistical semantics }} & \multicolumn{2}{|c|}{ discriminant group $5=\mathrm{N}$} & \multicolumn{2}{|c|}{ Non-discriminant group $5=\mathrm{N}$} & \multirow{3}{*}{$\begin{array}{c}\text { difference } \\
\text { between } \\
\text { two means }\end{array}$} & \multirow{3}{*}{$\begin{array}{c}\begin{array}{c}\text { Value } \\
(\mathrm{t})\end{array} \\
24.296\end{array}$} & \multirow{3}{*}{$\begin{array}{c}\begin{array}{c}\text { validity } \\
\text { coefficient }\end{array} \\
0.993\end{array}$} \\
\hline & & & \multirow{2}{*}{$\frac{\text { mean }}{7.480}$} & \multirow{2}{*}{$\begin{array}{c}\begin{array}{c}\text { Std. } \\
\text { deviation } \pm\end{array} \\
0.577\end{array}$} & \multirow{2}{*}{$\begin{array}{c}\text { mean } \\
3.160\end{array}$} & \multirow{2}{*}{$\begin{array}{c}\begin{array}{c}\text { Std. } \\
\text { deviation } \pm\end{array} \\
0.251\end{array}$} & & & \\
\hline & $\begin{array}{l}\text { Test of handstand position on the } \\
\text { parallel bars with force }\end{array}$ & NO. & & & & & & & \\
\hline & $\begin{array}{c}\text { Test of handstand position on the } \\
\text { parallel bars with bending your } \\
\text { arms }\end{array}$ & NO. & 7.530 & 0.534 & 2.444 & 0.779 & 5.086 & 18.658 & 0.989 \\
\hline & $\begin{array}{l}\text { Testing the numbers of side swings } \\
\text { from the parallel leaning on a } \\
\text { mushroom with one ring }\end{array}$ & NO. & 20.133 & 1.711 & 10.832 & 0.766 & 9.302 & 17.191 & 0.987 \\
\hline & $\begin{array}{l}\text { Testing the numbers of side swings } \\
\text { from the parallel leaning on rings }\end{array}$ & NO. & 39.333 & 1.030 & 29.419 & 1.084 & 9.917 & 20.273 & 0.990 \\
\hline & $\begin{array}{l}\text { Testing the numbers of side swings } \\
\text { from the intersected leaning }\end{array}$ & $\mathrm{cm}$ & 43.667 & 1.303 & 31.271 & 0.862 & 12.396 & 27.485 & 0.995 \\
\hline \multirow{2}{*}{ 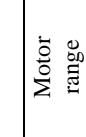 } & $\begin{array}{l}\text { the motor range of the flexor joints } \\
\text { of the shoulder }\end{array}$ & NO. & 65.000 & 0.853 & 55.250 & 0.866 & 9.750 & 27.788 & 0.995 \\
\hline & $\begin{array}{l}\text { the motor range of the long joints } \\
\text { of the shoulder }\end{array}$ & NO. & 115.667 & 1.775 & 94.083 & 2.109 & 21.583 & 27.123 & 0.995 \\
\hline \multicolumn{2}{|c|}{$\begin{array}{l}\text { Assessing the performance level of FLOB } 360 \\
\text { skill on the pommel horse from (15) fifteen } \\
\text { points }\end{array}$} & NO. & 11.583 & 0.485 & 8.200 & 0.449 & 3.383 & 17.729 & 0.988 \\
\hline
\end{tabular}

The Significant statistical level at of $0.05=2.31$

It's clear from the Table (2), relating to the differences between the discriminant and non- discriminant groups to find the validity of the physical tests and to assess the performance level of the skills, that there are significant differences in all physical and skills variables between the two groups in favor of the discriminant group, where the calculated value of $(\mathrm{T})$ ranges between (7.331 to 27.788 ) and these values at the 0.05 level and also the coefficient of validity ranges between ( 0.933 to 0.995$)$, which confirms that the variables are discriminatory validity, and these variables measure what they were put for.

\section{B- Coefficient of reliability}

To determine the degree of reliability of tests, the two researchers used the method of test - retest by applying the tests and re-applying them after a period of ten (10) days on a group of junior players, out the research sample and from the same research community.

Table (3)

Reliability coefficients for the physical tests and the performance level of the skill, under the study

\begin{tabular}{|c|c|c|c|c|c|c|c|c|}
\hline \multirow{2}{*}{\multicolumn{3}{|c|}{ Statistical semantics }} & \multirow{3}{*}{ variables } & \multirow{2}{*}{\multicolumn{2}{|c|}{$\begin{array}{l}\text { First implementation } \\
5=\mathrm{N}\end{array}$}} & \multicolumn{2}{|c|}{$\begin{array}{l}\text { second- implementation } \\
\text { (discriminant) } 5=\mathrm{N}\end{array}$} & \multirow{2}{*}{$\begin{array}{l}\text { Reliability } \\
\text { coefficient }\end{array}$} \\
\hline & & & & & & & & \\
\hline & & & & mean & deviation \pm & mean & deviation \pm & \\
\hline \multirow{14}{*}{ 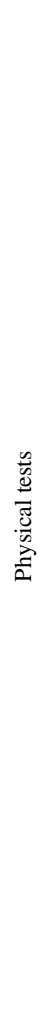 } & \multirow{7}{*}{ 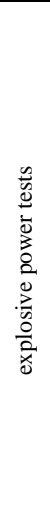 } & $\begin{array}{l}\text { Test of lifting up the hips highly from the inverted } \\
\text { grasp on the jumping pommel horse during }(15 \mathrm{~s})\end{array}$ & NO. & 10.074 & 1.493 & 10.157 & 1.461 & 0.921 \\
\hline & & $\begin{array}{l}\text { Test of lifting up the two legs to touch wall bar with } \\
\text { the two insteps with the maximum number during } \\
\qquad(15 \mathrm{sec})\end{array}$ & NO. & 10.152 & 1.463 & 10.235 & 1.433 & 0.933 \\
\hline & & $\begin{array}{l}\text { Test of lifting up the two legs backwardly to touch the } \\
\text { tester's hand when lying on the pommel during (15 } \\
\text { sec) }\end{array}$ & NO. & 13.501 & 2.241 & 13.710 & 2.248 & 0.896 \\
\hline & & $\begin{array}{l}\text { Test of lifting up the hips forwardly, intersecting the } \\
\text { two hands behind the head, touching the tester's hand, } \\
\text { lying on the pommel horse during }(15 \mathrm{~S})\end{array}$ & NO. & 13.920 & 1.430 & 14.003 & 1.464 & 0.972 \\
\hline & & $\begin{array}{l}\text { Test of turning the Body from the handstand position } \\
\text { inside two circles during }(15 \mathrm{~S})\end{array}$ & NO. & 9.693 & 2.147 & 9.860 & 2.102 & 0964 \\
\hline & & $\begin{array}{l}\text { Test of stretching the two arms when the chin is above } \\
\text { the bar with the maximum number during } 15 \mathrm{~S} \text { ) }\end{array}$ & NO. & 10.209 & 2.089 & 10.417 & 2.072 & 0.928 \\
\hline & & Test of stability and stalling on pommel horse & $\mathrm{sec}$ & 22.643 & 8.934 & 23.417 & 9.047 & 0.909 \\
\hline & \multirow{7}{*}{ 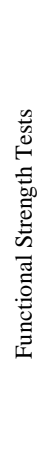 } & Test of $\mathrm{V}$-angular sitting position on the parallel bars & $\sec$ & 7.631 & 3.340 & 7.904 & 3.464 & 0.889 \\
\hline & & Test of handstand on the pommel and stability on it & $\mathrm{sec}$ & 16.373 & 5.197 & 16.790 & 5.252 & 0.876 \\
\hline & & $\begin{array}{l}\text { Test of the inverted hung (grasp) on the pommel and } \\
\text { stability in backward position }\end{array}$ & $\mathrm{sec}$ & 7.531 & 3.085 & 7.781 & 3.168 & 0.951 \\
\hline & & $\begin{array}{l}\text { Test of the inverted hung (grasp) on the pommel and } \\
\text { stability in forward position }\end{array}$ & $\sec$ & 3.519 & 1.871 & 3.720 & 1.888 & 0.960 \\
\hline & & $\begin{array}{l}\text { Test of planch, open legs from behind, on the parallel } \\
\text { bars from the angular leaning position }\end{array}$ & NO. & 5.951 & 2.489 & 6.160 & 2.549 & 0.948 \\
\hline & & $\begin{array}{l}\text { Test of handstand position on the parallel bars with } \\
\text { force }\end{array}$ & NO. & 5.320 & 2.247 & 5.487 & 2.214 & 0.938 \\
\hline & & $\begin{array}{l}\text { Test of handstand position on the parallel bars with } \\
\text { bending your arms }\end{array}$ & NO. & 4.987 & 2.678 & 5.205 & 2.637 & 0.949 \\
\hline
\end{tabular}




\begin{tabular}{|c|c|c|c|c|c|c|c|}
\hline \multicolumn{3}{|c|}{ Statistical semantics } & \multicolumn{2}{|c|}{$\begin{array}{l}\text { First implementation } \\
5=\mathrm{N}\end{array}$} & \multicolumn{2}{|c|}{$\begin{array}{c}\text { second- implementation } \\
\text { (discriminant) } 5=\mathrm{N}\end{array}$} & \multirow{2}{*}{$\begin{array}{l}\text { Reliability } \\
\text { coefficient }\end{array}$} \\
\hline & & variables & & deviation \pm & & deviation \pm & \\
\hline & $\begin{array}{l}\text { Testing the numbers of side swings from the parallel } \\
\text { leaning on a mushroom with one ring }\end{array}$ & NO. & 15.483 & 4.095 & 15.774 & 4.871 & 0.922 \\
\hline & $\begin{array}{l}\text { Testing the numbers of side swings from the parallel } \\
\text { leaning on rings }\end{array}$ & NO. & 34.375 & 5.199 & 34.708 & 5.162 & 0.929 \\
\hline & $\begin{array}{l}\text { Testing the numbers of side swings from the } \\
\text { intersected leaning }\end{array}$ & $\mathrm{cm}$ & 37.469 & 6.423 & 37.885 & 6.377 & 0.900 \\
\hline$\stackrel{\infty}{\infty}$ & the motor range of the flexor joints of the shoulder & NO. & 60.125 & 5.050 & 60.458 & 5.030 & 0.941 \\
\hline$\stackrel{0}{\stackrel{0}{0}}$ & the motor range of the long joints of the shoulder & NO. & 104.875 & 11.187 & 105.792 & 11.329 & 0.941 \\
\hline Assessing & $\begin{array}{l}\text { performance level of FLOB } 360 \text { skill on the pommel } \\
\text { horse from (15) fifteen points }\end{array}$ & NO. & 9.892 & 1.788 & 10.003 & 1.786 & 0.938 \\
\hline
\end{tabular}

Significant at the level of 0.05 level $=2.26$

It's clear from table (3), relating to the variances between the first implementation and the second implementation on the two discriminant and non- discriminant groups to find the reliability of the physical tests and the performance level of skills, that there aren't any significant variances in all physical variables and in the performance level of skill between the first and the second implementation, where the reliability coefficient ranges between (0.876 to 0.972), which confirms that the variables are stable and they give the same results if re-applied again on the same sample at the same conditions.

\section{The design of the Program}

(After revising many programs in the field of gymnastics, the used tools and apparatus, as well as the references of training and gymnastics $(15: 272),(23: 10),(4: 66),(24$ $: 15)$ and also after consulting the experienced specialists of gymnastics, in addition to the personal experience of the two researchers because they are teaching staff members and trainers for various technical stages until the first class), they could choose and determine the content of the program of the apparatus and tools that could be used in proposed and gradual educational steps simulating to the performance of the skill, taking into account the healthy performance during the use of tools and apparatus, attachments ( 5 ) and (6)

The educational steps that would be used in the program, by using the assistive tools and apparatus, were presented on five members of the staff that have the experience not less than ten years in the field of training Gymnastics. After the experts had approved the educational steps, by using the assistive tools and apparatus, in the final form, the time of the training sessions has been calculated as the following:

For the time of each exercise, the training session time has been divided on the number of exercises in the training session, as for the number of repetitions for each exercise; it was determined by dividing the largest number of repetitions on 2, during the prepared time for each exercise. Also the break time between each exercise was recorded, as well as the time of transition from a group to another group by taking the pulse as a criterion to determine the average of this time (17: 235).

This study has resulted in the following:
- The average repetition time of the actual performance for each exercise of the functional exercises was (15seconds) during the training session.

- the training session's time is ( 105 minutes daily) distributed as the followings : (10 minutes) ten minutes warm-up , from ( 50 to 55 minutes ) training on the educational steps of the functional exercises by using the assistive tools and apparatus, from ( 30 to 35 minutes ) technical, ( 5 minutes ) for relaxing and finishing .

- The average break between the repetition of each exercise is $(30 \mathrm{sec})$ and between groups is $(45 \mathrm{sec})$ at the moment that the average of pulses reaches approximately (110 - 130) pulses / minutes (17: 219), attachments (5), (6)

\section{The applied steps of the research:}

Pre - measurements (tests):

Pre-Measurements were carried out in the period from 8/1 $/ 2013$ to $10 / 1 / 2013 \mathrm{AD}$ on the study's sample for the physical measurements and for assessing the performance level of the skills, under the discussion.

\section{The implementation of the research's experiment:}

The basic experiment has been applied in the period from $12 / 1 / 2013$ to $11 / 4 / 2013 \mathrm{AD}$

\section{Post-measurements:}

Post- measurements were carried out in the period from $13 / 4 / 2013$ to $15 / 4 / 2013$ on the study's sample for the physical measurements and for assessing the performance level of the skills, under the discussion.

\section{Statistical treatments:}

Data of research's results were analyzed by using the SPSS program to calculate or find:

- Arithmetic mean.

- Deviation standard.

- Coefficient of Skewness, Kurtosis.

- Variances Tests for each group, both groups.

- Percentage of improvement.

Presentation and discussion of the results: 
First: Presentation of results:

Table (4)

Variances between the pre and post- measurements of the control group in the physical tests and the degree of the performance level of the skill in the research.

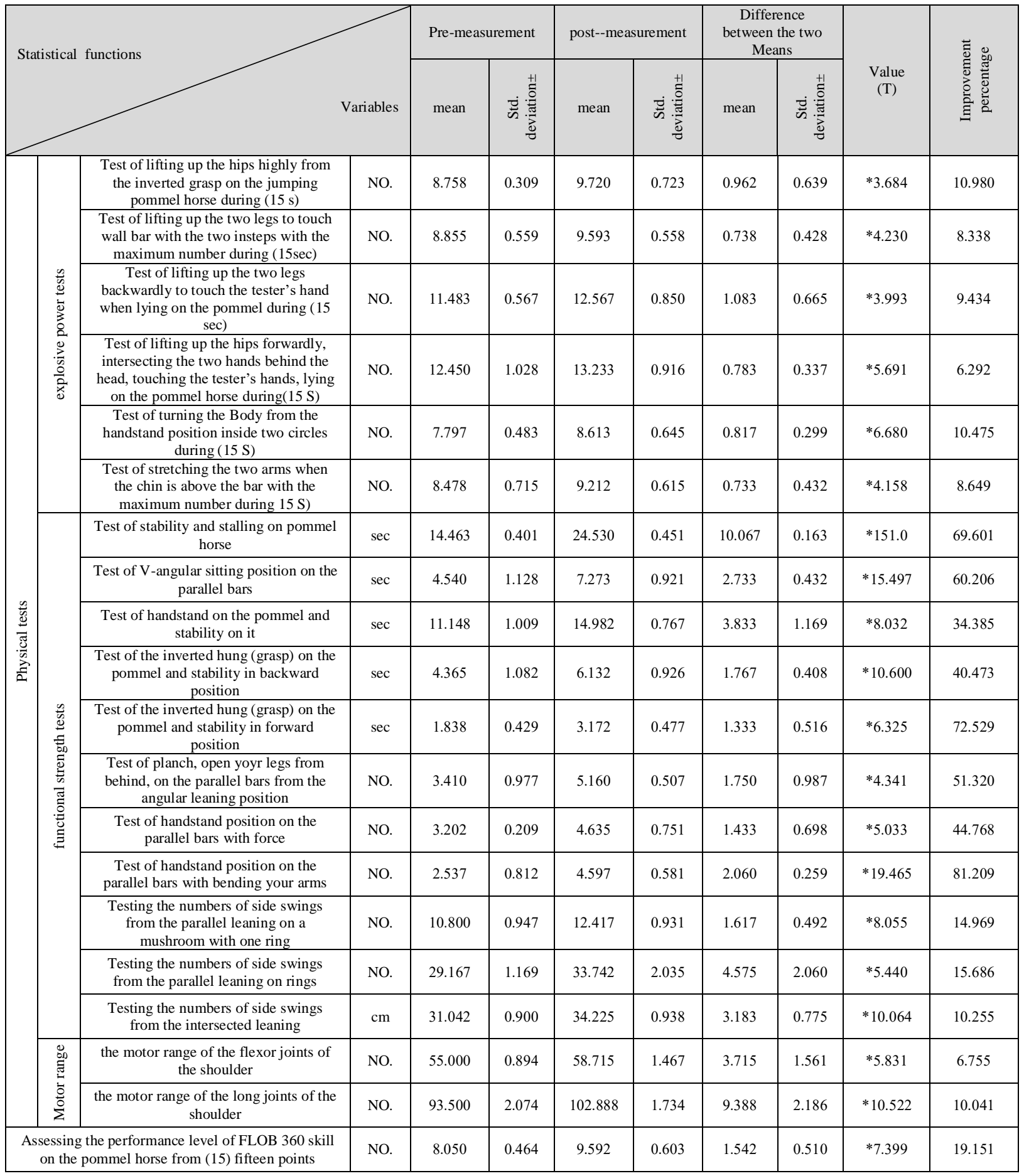

It's clear from table (5), Variances between the pre and postmeasurements of the control group in the physical tests and the degree of the performance level of the skill in the research, that there are variances between the two measurements at the 0.05 level in the all tests as the value of (T) ranges from (5.343 to 86.714) and the improvement percentage ranges from $(6.292 \%$ to $81.209 \%)$. 
Table (5)

Variances between the pre and post- measurements of the experimental group in the physical tests and the degree of the performance level of the skill in the research.

\begin{tabular}{|c|c|c|c|c|c|c|c|c|c|c|c|}
\hline \multirow{2}{*}{\multicolumn{4}{|c|}{ Statistical functions }} & \multicolumn{2}{|c|}{ Pre-measurement } & \multicolumn{2}{|c|}{ post--measurements } & \multicolumn{2}{|c|}{$\begin{array}{l}\text { Differences between } \\
\text { the two Means }\end{array}$} & \multirow[b]{2}{*}{$\begin{array}{l}\text { Value } \\
(\mathrm{T})\end{array}$} & \multirow{2}{*}{ 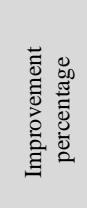 } \\
\hline & & & & mean & 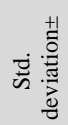 & mean & 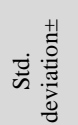 & mean & $\dot{\frac{j}{n}} \cdot \frac{\overbrace{0}^{+1}}{\frac{\pi}{3}}$ & & \\
\hline \multirow{6}{*}{\multicolumn{2}{|c|}{$\begin{array}{l}0 \\
0 \\
0 \\
0 \\
0 \\
0 \\
0 \\
0 \\
0 \\
0 \\
0 \\
0 \\
0 \\
0 \\
0\end{array}$}} & $\begin{array}{l}\text { Test of lifting up the hips highly } \\
\text { from the inverted grasp on the } \\
\text { jumping pommel horse during (15 } \\
\text { s) }\end{array}$ & NO. & 8.782 & 0.295 & 11.350 & 0.752 & 2.568 & 0.709 & $* 8.878$ & 29.247 \\
\hline & & $\begin{array}{l}\text { Test of lifting up the two legs to } \\
\text { touch wall bar with the two insteps } \\
\text { with the maximum number during } \\
(15 \mathrm{sec})\end{array}$ & NO. & 8.633 & 0.493 & 11.578 & 0.868 & 2.945 & 1.042 & *6.922 & 34.112 \\
\hline & & $\begin{array}{c}\text { Test of lifting up the two legs } \\
\text { backwardly to touch the tester's } \\
\text { hand when lying on the pommel } \\
\text { during }(15 \mathrm{sec})\end{array}$ & NO. & 11.707 & 1.010 & 14.823 & 0.761 & 3.117 & 1.429 & $* 5.343$ & 26.623 \\
\hline & & $\begin{array}{l}\text { Test of lifting up the hips } \\
\text { forwardly, intersecting the two } \\
\text { hands behind the head, touching } \\
\text { the tester's hand, lying on the } \\
\text { pommel horse during }(15 \mathrm{~S})\end{array}$ & NO. & 12.243 & 0.886 & 14.610 & 0.818 & 2.367 & 0.804 & $* 7.209$ & 19.330 \\
\hline & & $\begin{array}{l}\text { Test of turning the Body from the } \\
\text { handstand position inside two } \\
\text { circles during }(15 \mathrm{~S})\end{array}$ & NO. & 8.072 & 0.521 & 11.822 & 0.713 & 3.750 & 0.758 & $* 12.114$ & 46.459 \\
\hline & & $\begin{array}{l}\text { Test of stretching the two arms } \\
\text { when the chin is above the bar } \\
\text { with the maximum number during } \\
15 \mathrm{~S} \text { ) }\end{array}$ & NO. & 8.408 & 0.728 & 11.942 & 0.612 & 3.533 & 1.244 & $* 6.959$ & 42.022 \\
\hline \multirow{13}{*}{ 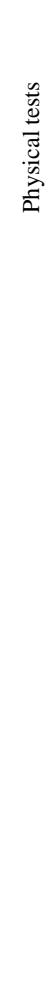 } & \multirow{11}{*}{ 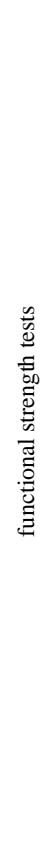 } & $\begin{array}{l}\text { Test of stability and stalling on } \\
\text { pommel horse }\end{array}$ & $\mathrm{sec}$ & 14.535 & 0.616 & 31.035 & 4.511 & 16.500 & 5.050 & $* 8.004$ & 113.519 \\
\hline & & $\begin{array}{c}\text { Test of V-angular sitting position } \\
\text { on the parallel bars }\end{array}$ & $\sec$ & 4.375 & 0.917 & 10.042 & 1.829 & 5.667 & 1.366 & *10.159 & 129.524 \\
\hline & & $\begin{array}{c}\text { Test of handstand on the pommel } \\
\text { and stability on it }\end{array}$ & $\mathrm{sec}$ & 11.482 & 1.169 & 21.598 & 1.394 & 10.117 & 0.286 & *86.714 & 88.111 \\
\hline & & $\begin{array}{l}\text { Test of the inverted hung (grasp) } \\
\text { on the pommel and stability in } \\
\text { backward position }\end{array}$ & $\sec$ & 4.460 & 0.852 & 9.960 & 1.019 & 5.500 & 1.000 & *13.472 & 123.318 \\
\hline & & $\begin{array}{l}\text { Test of the inverted hung (grasp) } \\
\text { on the pommel and stability in } \\
\text { forward position }\end{array}$ & $\sec$ & 1.982 & 0.423 & 5.715 & 1.152 & 3.733 & 1.071 & $* 8.540$ & 188.394 \\
\hline & & $\begin{array}{l}\text { Test of planch, open your legs } \\
\text { from behind, on the parallel bars } \\
\text { from the angular leaning position }\end{array}$ & NO. & 3.252 & 0.875 & 8.352 & 1.036 & 5.100 & 0.837 & *14.931 & 156.843 \\
\hline & & $\begin{array}{l}\text { Test of handstand position on the } \\
\text { parallel bars with force }\end{array}$ & NO. & 3.182 & 0.207 & 7.682 & 0.661 & 4.500 & 0.548 & $* 20.125$ & 141.435 \\
\hline & & $\begin{array}{c}\text { Test of handstand position on the } \\
\text { parallel bars with bending your } \\
\text { arms }\end{array}$ & NO. & 2.685 & 0.800 & 8.098 & 0.811 & 5.413 & 0.426 & *31.107 & 201.614 \\
\hline & & $\begin{array}{l}\text { Testing the numbers of side swings } \\
\text { from the parallel leaning on a } \\
\text { mushroom with one ring }\end{array}$ & NO. & 11.132 & 0.914 & 19.282 & 1.640 & 8.150 & 1.605 & *12.441 & 73.215 \\
\hline & & $\begin{array}{l}\text { Testing the numbers of side swings } \\
\text { from the parallel leaning on rings }\end{array}$ & NO. & 29.000 & 0.894 & 37.710 & 2.098 & 8.710 & 2.664 & *8.009 & 30.034 \\
\hline & & $\begin{array}{l}\text { Testing the numbers of side swings } \\
\text { from the intersected leaning }\end{array}$ & $\mathrm{cm}$ & 31.042 & 0.900 & 43.167 & 1.472 & 12.125 & 1.787 & *16.619 & 39.060 \\
\hline & \multirow{2}{*}{ 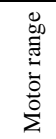 } & $\begin{array}{l}\text { the motor range of the flexor joints } \\
\text { of the shoulder }\end{array}$ & NO. & 55.382 & 1.458 & 64.380 & 2.511 & 8.998 & 2.002 & $* 11.010$ & 16.248 \\
\hline & & $\begin{array}{l}\text { the motor range of the long joints } \\
\text { of the shoulder }\end{array}$ & NO. & 92.437 & 1.937 & 116.213 & 2.353 & 23.777 & 2.987 & *19.500 & 25.722 \\
\hline \multicolumn{3}{|c|}{$\begin{array}{l}\text { Assessing the performance level of FLOB } 360 \\
\text { skill on the pommel horse from (15) fifteen } \\
\text { points }\end{array}$} & NO. & 8.100 & 0.420 & 12.073 & 0.778 & 3.973 & 0.741 & *13.127 & 49.053 \\
\hline
\end{tabular}

Significant at the level of $0.05=2.57$

It's clear from table (5), Variances between the pre and postmeasurements of the experimental group in the physical tests and in the degree of the performance level of the skill in the research, that there are variances between the two measurements at the 0.05 level in the all tests as the value of
(T) ranges from (5.343 to 86.714) and these values are greater than the Tabulated value of $(\mathrm{T})$ at the 0.05 level and also the percentage of improvement ranges between $\%$ (16.248\% to $201.614 \%)$. 
Table (6)

Variances between the experimental group and the control group in the post- measurement in the physical tests and the degree of the performance level of the skill in the research.

\begin{tabular}{|c|c|c|c|c|c|c|c|c|c|c|}
\hline \multirow{2}{*}{\multicolumn{4}{|c|}{ Statistical functions }} & \multicolumn{2}{|c|}{$\begin{array}{l}\text { Control group } \\
\mathrm{N}=6\end{array}$} & \multicolumn{2}{|c|}{$\begin{array}{l}\text { Experimental group } \\
\qquad \mathrm{N}=6\end{array}$} & \multirow{2}{*}{ 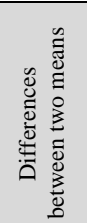 } & \multirow[b]{2}{*}{ Value (T) } & \multirow{2}{*}{ 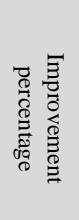 } \\
\hline & & & & mean & 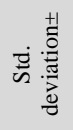 & mean & 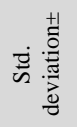 & & & \\
\hline \multirow{19}{*}{ 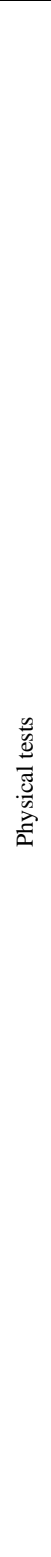 } & \multirow{6}{*}{ 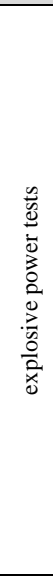 } & $\begin{array}{l}\text { Test of lifting up the hips highly from } \\
\text { the inverted grasp on the jumping } \\
\text { pommel horse during }(15 \mathrm{~s})\end{array}$ & NO. & 11.350 & 0.752 & 9.720 & 0.723 & 1.630 & *3.826 & 14.361 \\
\hline & & $\begin{array}{l}\text { Test of lifting up the two legs to touch } \\
\text { wall bar with the two insteps with the } \\
\text { maximum number during }(15 \mathrm{sec})\end{array}$ & NO. & 11.578 & 0.868 & 9.593 & 0.558 & 1.985 & $* 4.711$ & 17.144 \\
\hline & & $\begin{array}{c}\text { Test of lifting up the two legs } \\
\text { backwardly to touch the tester's hand } \\
\text { when lying on the pommel during ( } 15 \\
\text { sec) }\end{array}$ & NO. & 14.823 & 0.761 & 12.567 & 0.850 & 2.257 & $* 4.847$ & 15.224 \\
\hline & & $\begin{array}{l}\text { Test of lifting up the hips forwardly, } \\
\text { intersecting the two hands behind the } \\
\text { head, touching the tester's hand, lying } \\
\text { on the pommel horse during }(15 \mathrm{~S})\end{array}$ & NO. & 14.610 & 0.818 & 13.233 & 0.916 & 1.377 & $* 2.747$ & 9.423 \\
\hline & & $\begin{array}{c}\text { Test of turning the Body from the } \\
\text { handstand position inside two circles } \\
\text { during (15 S) }\end{array}$ & NO. & 11.822 & 0.713 & 8.613 & 0.645 & 3.208 & $* 8.179$ & 27.139 \\
\hline & & $\begin{array}{l}\text { Test of stretching the two arms when } \\
\text { the chin is above the bar with the } \\
\text { maximum number during } 15 \mathrm{~S} \text { ) }\end{array}$ & NO. & 11.942 & 0.612 & 9.212 & 0.615 & 2.730 & *7.709 & 22.861 \\
\hline & \multirow{11}{*}{ 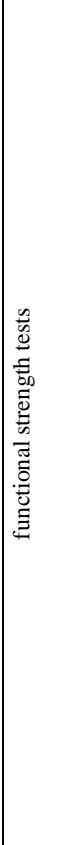 } & $\begin{array}{l}\text { Test of stability and stalling on } \\
\text { pommel horse }\end{array}$ & $\mathrm{sec}$ & 31.035 & 4.511 & 24.530 & 0.451 & 6.505 & *3.515 & 20.960 \\
\hline & & $\begin{array}{l}\text { Test of V-angular sitting position on } \\
\text { the parallel bars }\end{array}$ & $\mathrm{sec}$ & 10.042 & 1.829 & 7.273 & 0.921 & 2.768 & $* 3.311$ & 27.568 \\
\hline & & $\begin{array}{l}\text { Test of handstand on the pommel and } \\
\text { stability on it }\end{array}$ & $\mathrm{sec}$ & 21.598 & 1.394 & 14.982 & 0.767 & 6.617 & $* 10.188$ & 30.635 \\
\hline & & $\begin{array}{l}\text { Test of the inverted hung (grasp) on } \\
\text { the pommel and stability in backward } \\
\text { position } \\
\end{array}$ & $\mathrm{sec}$ & 9.960 & 1.019 & 6.132 & 0.926 & 3.828 & *6.813 & 38.437 \\
\hline & & $\begin{array}{l}\text { Test of the inverted hung (grasp) on } \\
\text { the pommel and stability in forward } \\
\text { position }\end{array}$ & $\mathrm{sec}$ & 5.715 & 1.152 & 3.172 & 0.477 & 2.543 & *4.996 & 44.503 \\
\hline & & $\begin{array}{l}\text { Test of planch, open your legs from } \\
\text { behind, on the parallel bars from the } \\
\text { angular leaning position }\end{array}$ & NO. & 8.352 & 1.036 & 5.160 & 0.507 & 3.192 & $* 6.780$ & 38.216 \\
\hline & & $\begin{array}{l}\text { Test of handstand position on the } \\
\text { parallel bars with force }\end{array}$ & NO. & 7.682 & 0.661 & 4.635 & 0.751 & 3.047 & *7.457 & 39.662 \\
\hline & & $\begin{array}{l}\text { Test of handstand position on the } \\
\text { parallel bars with bending your arms }\end{array}$ & NO. & 8.098 & 0.811 & 4.597 & 0.581 & 3.502 & *8.601 & 43.239 \\
\hline & & $\begin{array}{l}\text { Testing the numbers of side swings } \\
(\gg \gg \gg>) \text { from the parallel leaning on } \\
\text { a mushroom with one ring }\end{array}$ & NO. & 19.282 & 1.640 & 12.417 & 0.931 & 6.865 & *8.917 & 35.604 \\
\hline & & $\begin{array}{l}\text { Testing the numbers of side swings } \\
(\gg \gg \gg) \text { from the parallel leaning on } \\
\text { rings }\end{array}$ & NO. & 37.710 & 2.098 & 33.742 & 2.035 & 3.968 & *3.326 & 10.523 \\
\hline & & $\begin{array}{l}\text { Testing the numbers of side swings } \\
(\gg \gg>) \text { from the intersected leaning }\end{array}$ & $\mathrm{cm}$ & 43.167 & 1.472 & 34.225 & 0.938 & 8.942 & $* 12.549$ & 20.714 \\
\hline & \multirow{2}{*}{ 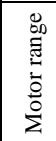 } & $\begin{array}{l}\text { the motor range of the flexor joints of } \\
\text { the shoulder }\end{array}$ & NO. & 64.380 & 2.511 & 58.715 & 1.467 & 5.665 & $* 4.771$ & 8.799 \\
\hline & & $\begin{array}{l}\text { the motor range of the long joints of } \\
\text { the shoulder }\end{array}$ & NO. & 116.213 & 2.353 & 102.888 & 1.734 & 13.325 & *11.166 & 11.466 \\
\hline \multicolumn{3}{|c|}{$\begin{array}{l}\text { Assessing the performance level of FLOB } 360 \text { skill } \\
\text { on the pommel horse from (15) fifteen points }\end{array}$} & NO. & 12.073 & 0.778 & 9.592 & 0.603 & 2.482 & $* 6.175$ & 20.555 \\
\hline
\end{tabular}

\section{Significant at the level of $0.05=2.22$}

It's clear from table (5), Variances between the experimental group and the control group in the post- measurement in the physical tests and the degree of the performance level of the skill in the research, that there are variances between the two groups at the 0.05 level in the all tests where the value of (T) ranges from (2.747 to 12.549$)$ and these values are greater than the Tabulated value of (T) at the 0.05 level and also the percentage of improvement ranges between \% $(7.799 \%$ to $44.503 \%)$.
The Validity coefficient ranges from (0.933 to 0.995$)$ which assure that the variables are marked as discriminant validity and they measure what they were put for.

\section{Second, discussing the results:}

In light of the results of statistical analysis of the study data, the two researchers tried to ensure the achievement of the study hypotheses and discuss these results, guided with the 
results of the related studies and the available scientific references.

\section{Discussing the first hypothesis:}

It's clear from table (5) that there are variances between the pre- and post- measurements in favor of the post measurement for the control group in the physical tests and the performance level of the FLOB 360 skill on the pommel horse apparatus where these values range from (13.684 to $19.465)$ and these values are greater than the tabulated value of $(\mathrm{T})$, and also the improvement percentage ranges from (6.292\% to $81.209 \%)$.

this means that the members of the control group had improved according to the results of post measurements and the performance level of the FLOB 360 skill on the pommel horse apparatus, compared with the pre- measurements , the two researchers may refer this improvement to the technical and physical training program that the members of the control group took like the experimental group except the functional strength exercises, and may be also the depending on the classical training routine to improve the strength, where its performance is not similar to the technical performance, all that have an impact in the high physical and technical level of the control group, all that is in addition to increasing the determined time for the training session for the control group, where it became six (6) times a week and the time of the session is 360 minutes, and this is different from the followed system of ( 5 ) times training session a week and 180 minutes for one session.

The two researchers think that the use of (the traditional method in training ) ( the training program ) had a positive impact on the variables of the research, but less than the experimental group, which used the functional strength exercises, and all that are consistent with the results of Susan Badran Mohammed ( 2002 ) (8 ), Fatima Mohammed phliphal ( 2003 ) ( 13) studies, which refer to the importance of the traditional method which cannot be overlooked because it helps in learning and training properly .

The two researchers think that these results also refer to learning and training in team and in groups which raised the motivation and the competitive sense between the juniors pushing them towards the superiority in performing the skills therefore this manner has a positive effect on the technical performance of FLOB 360 skill.

This is in line with the results of Mohammad Hassan Allawy and Abu Ela Abdul Fattah (1984) that the training is systematic, physical and well-organized process in order to develop the physical abilities of the individual.

\section{(18: 177)}

It is clear from Table (4) that there is an improvement in the results of the post- measurement than the pre- measurement in the level of the technical performance skills on the pommel horse for FLOB 360 skill, this result reached $19.151 \%$ for the control group, and this confirms that there is a modest improvement in variables of the functional strength and in the degree of the technical performance on the pommel horse for the control group and in favor of the post- measurement.

The two researchers think this improvement happened because the control group was subjected to technical exercises and to performing the FLOB 360 skill by the traditional method, which resulted in raising the level of technical performance of the FLOB 360 skill on the pommel horse, as well as the improvement in the variables of the functional strength foe the control group as a natural result of these exercises, and thus the first hypothesis occurred(came true), which says " There are significant statistical differences between the pre and post measurements of the physical variables and the performance level of the (360 ${ }^{\circ}$ FLOPS) skill for the Gymnastics juniors under the age of 13 on the pommel horse in favor of the control group and the post-measurement'.

\section{Discussing the second hypothesis:}

It's clear from table (5), Variances between the pre and postmeasurements of the experimental group in the physical tests and in the degree of the performance level of the skill in the research, that there are variances between the two measurements at the 0.05 level in the all tests as the value of (T) ranges from (5.343 to 86.714) and these values are greater than the Tabulated value of $(\mathrm{T})$ at the 0.05 level and also the percentage of improvement ranges between $\%$ (16.248\% to $201.614 \%)$.

This means that the members of the experimental group improved in the results of the post-measurements for the explosive power, the functional strength, the motor rang and the technical level of the FLOB 360 skill on the pommel horse apparatus.

The two researchers refer these results to the applying of the proposed exercises by using the functional strength exercises on the experimental group, where these exercises have a set of special exercises to develop the muscular strength of the arms, the abdomen, and the back and by using the functional strength exercises. And also the rationing physical loads in the training sessions were appropriate for the level of the sample and this method took into account the individual differences between the juniors, which reflected positively on their level.

These exercises have a tremendous resistance on the muscle during the performance, as a result of continuous rationing training of the proposed exercises which included a variety of different exercises, which made a remarkable progress in the level of performance skills.

These results are consistent with the results of each Kamal Mahrous ( 1999 ) ( 14) and Ozmun (2000 AD) (37) that the effect of the training program led to improvements in some strength motor 's variables, the level of performance and the muscular strength of the arms, as well as the explosive power.

Mohammad Hassan Allawy ( 2001 ) ( 19) refers to the improvement of one physical variable increasingly $t$ happens in the case of developing some physical variables 
with a certain degree and this is consistent with Abul-Ela Ahmed Abdel- Fattah and others ( 1997 ) (1 ) in that the muscular strength related with some of the physical variables, and Mohamed Sobhy Hassanein adds ( 1995 ) (20 ) that the muscular strength is considered one of the important indicators of the state of fitness as indicated by Khayraya Ibrahim diabetes , Mohammed Jaber Brikaa and others ( 2001 ) (6).

The regular continuous training helps to strengthen the abdominal and the back muscles, especially by doing the exercises on the floor because this method is much better than the training on the prepared apparatus for this, where these apparatus may be not effective and sometimes unsafe.

The results of this study are similar to the results of a study of Hegazy Abdel Sayed Ibrahim ( 1981 ) (5) Samia Abdel Rahman Osman (1994) (7) Stricevic et al (1991 m) (39), Norris (1993 m) (35), O-Sullivan et al (1998 m) (36) Plamondon et al (1999 m) (38) where they reached that strengthen of the abdominal muscles and the corresponding back muscles (muscular balance), a balance between the front muscle ( abdominal muscles ) and the corresponding back ( back muscles ) in an effective manner, depends on the choice of a set of exercises suiting every sport .

The two researchers believe that the FLOB 360 skill requires specific physical abilities of the player; the most important abilities are the balance and strength of the abdomen and the back muscles.

The results of the study are consistent with the study of both Cress, et al (1996) (27), Yasumura, (2000) (40) Marijke. Et al (2004) (31), Cymara, et al (2004) (28) where they pointed that there is a relationship between the development of components of the functional strength and the high level of performance, and also the functional strength exercises contributes in improving the muscular strength and the balance.

And Aziz Gebaly (2000 AD) confirms that the muscular strength is one of the most important physical elements needed by gymnast because all his moves depend on how to move his body, and the muscles control these movements through the contraction and extroversion from one place to another, the more the muscles stronger, the greater the effectiveness of these contractions. (11: 351-360)

The results of the table (5) show an improvement in the results of the post-measurement other than the premeasurement in the performance level of FLOB360 skill on the pommel horse, as a percentage of $(49.053 \%)$ for the experimental group, and this confirms that there is a great improvement in the variables of the explosive power, the functional strength, the motor rang and the technical level of the FLOB 360 skill on the pommel horse apparatus for the experimental group and in favor of the post-measurement .

These results are consistent with the study of both Cress et el (1996 m) (27), Yasumura, et al (2000 m) (40) that say the functional strength exercises contribute in improving the muscular strength and balance, which in turn contributes in raising the performance level of the skills.
Thus, the second hypothesis has come true, which states that " There are significant statistical differences between the pre and post measurements of the physical variables and the performance level of the (360 ${ }^{\circ}$ FLOPS) skill for the Gymnastics juniors under the age of 13 on the pommel horse in favor of the experimental group and the postmeasurement.

\section{Discussing the third hypothesis:}

It's clear from table (6), Variances between the experimental group and the control group in the post- measurement in the physical tests and the degree of the performance level of the skill in the research, that there are variances between the two groups at the 0.05 level in the all tests where the value of $(\mathrm{T})$ ranges from (2.747 to 12.549$)$ and these values are greater than the Tabulated value of $(\mathrm{T})$ at the 0.05 level and also the percentage of improvement ranges \% from $(7.799 \%$ to $44.503 \%$ ) between the two groups and in favor of the experimental group, and this means significant outrival to the experimental group's members, applied on them the extra exercises program of the functional strength, rather than the members of the control group, applied on them The traditional program without functional strength exercises.

The two researchers think that these differences brought out because the the experimental group was subjected to the proposed exercises program by the researchers, but the control group followed the proposed exercises from the faculty, where the propsed exercises contain some of functional strength programs which helps to strengthen the core muscles ( abdominal and back muscles ) and thus also help in developing the other physical variables, which led to the existence of these statistical variances between the two groups in the physical variables under the discussion and in favor of the experimental group .

these results are consistent with the study of both Chris and others Cress et al (1996 m) (27), Yasumura et al (2004 m) (40), Cymara et al (2004 m) (28), in that the functional strength exercises contribute in improving the muscular strength of the core muscles, the muscular balance and the functional efficiency of the various organs of the body .

the results of both Cress et al (1996 m) (27) and Azza Khalil Mahmoud ( 2007 ) ( 10) that the functional strength exercises help in improving some of the physical variables ( strength - balance ).

the two researchers think that the statistical significant variances in the performance level of skills, for the experimental group, refer to that the juniors benefited from the bases of the set of proposed exercises, and the juniors benefited from the training sessions specially the part of the warming-up, the exercises of the main part to of the FLOB 360 skill by the dependence position, the hands movements and the in-line body, and also by showing the definition of the movements and training to all juniors, and all that come by employing the main part exercises, of strengthening the abdominal and back muscles, to improve the performance level of FLOB 360 skill, this is consistent with Nadia Demerdash, Ikhlas Nour eddine, Ferial Abdel- Aziz results 
( 1987 ) (25) that the training programs lead to improve the performance (13).

The two researchers may refer this progress to the functional strength exercises and what contained of directed exercises towarrds the goal of the training.

Schmitz Dave 'S (2003) enhanced that the characteristics of the functional strength exercises emphasizes the core where the muscles of the strong core link the lower limb with the upper, in addition to that the functional strength exercises include the movements of multi-directional by focusing on one single Limb which make it one of the best exercises to improve the strength of the muscles of the core (mid-body) and balance. (29: 242)

As shown from the table (6) that the differences between in the percentage of the improvement between the experimental and the control groups in the degree of the performance level of FLOB 360 skill on the pommel horse, as $(20.555 \%)$ for the experimental group , and this means the significant outrival to the experimental group's members, applied on them the extra exercises program of the functional strength, rather than the members of the control group, applied on them The traditional program without functional strength exercises.

The two researchers refer these variances to the main part of exercises that contain a set of exercises that strengthen the abdominal muscles and the corresponding muscles " making muscular balance " where these muscles are considered as the muscular core of the body, and Vath Azab shows ( 1993 ) ( 12) that the sense of the muscular core of the body ( abdomen - back ) leads to ease of the motion control, therefore Centering helps essentially in improving the performance level of the FLOB skill 360.

And the previous results are consistent with the results of Nadia Demerdash , Ikhlas Noor al-Din , Farid Abdel Aziz ( 1987 ) ( 22), Striceve (1991 m ) ( 39), and Norris (1993 m) (35) which say "strengthening the core muscles, the abdominal and the corresponding back muscles, lead to the ( muscular balance), which have a positive effect on the performance level of the skills.

Thus, the third hypothesis has been achieved, which states that " There are significant statistical variances between the control and experimental groups in the post-measurement for each of the physical variables and the performance level of the $\left(360^{\circ}\right.$ FLOPS) skill for the Gymnastics juniors under the age of 13 on the pommel horse in favor of the experimental as a result of using the functional strength exercises on the pommel horse apparatus".

\section{Conclusions:}

In light of the objectives and the hypotheses of the research and their characteristics, and also depending on the statistical treatments and their results, the two researchers concluded the following:

1. The proposed program that uses the functional strength exercises, leads to improve the fitness level of the research's sample.
2. The proposed program that uses the functional strength exercises, leads to improve the level of the technical performance of the skill of the research.

3. The proposed functional strength exercises led to better physical and technical results for the experimental group with comparing to the control group.

Recommendations:

In light of the objectives of the research and the conclusions, the two researchers recommend the following:

1. Caring about the functional strength exercises for the muscles of the arms, the abdomen, and the back, to improve the level of the technical performance of the skill of the research.

2. The use of the proposed functional strength exercises at the beginning of the training season during the performance stage to reduce some of the problems faced by players such as the weakness of the front abdominal muscle, the strength and the shortness the back muscles of the Trunk, where this requires strengthening the abdominal muscles and lengthen the back muscles of the Trunk, which leads to raise the performance level of the skill of the research.

3. Making further researches and studies on the most important exercises that contribute in developing of muscular strength and the best ways to be rationed.

4. Taking into account the similarity of the performance of the selected functional strength exercises with the shape of the technical performance of the skill of the research.

5. Making similar studies at different ages with using the functional strength exercises.

6. Making similar studies on the other apparatus of gymnastics.

References:

\section{Arabic References:}

1. Abu Ela Ahmed Abdel Fattah, Mohamed Sobhy Hassanein : Physiology, morphology of Sports and the measurement methods of evaluating, Cairo , Dar El-fakr Alaraby 1997 AD

2. Ahmed Mohammed Khater, Ali Fahmy El- Bak : measurement in the field of sports, Dar El-ktab El-hadeth, Cairo, 1996 AD

3. Compulsory skills for the artistic Men's Gymnastics; sports season 2009/2010 AD

4. Gamal Abdel -Aziz Al Sharhan : the educational methods and the developments in the educational technology, King Fahd National library, Riyadh , First edition, $2000 \mathrm{AD}$

5. Hegazy Abdel Sayed Ibrahim : the effect of static and dynamic exercises for patients with Lower back pain, Unpublished MA Thesis, Higher Institute for physiotherapy, Cairo University, 1981

6. Khiarya Ibrahim Al-Sukary and others: Management of the training of the musculoskeletal 
system of the human body, El-Maaraf institution , Alexandria, 2001

7. Samia Abdel Rahim Osman : "The impact of the therapeutic program exercises for back pain for empolyees in the Culture Palaces Authority, Unpublished MA Thesis , Faculty of Physical Education for Girls , Cairo 1994 AD

8. Susan Mohammed Badran : " the effective of the use of the educational technology methods on learning some basic skills in volleyball ," Unpublished MA Thesis , Faculty of Physical Education Girls, Helwan University, 2002

9. Adel Abdul Baseer Ali : the theories and the scientific bases of the training modern gymnastics, the second part, Dar Al-Fikr Al Arabi , Cairo $1998 \mathrm{AD}$

10. Azza Khalil Mahmoud " the effective of the functional strength exercises on the gene Superoxide dismutase and some physical variables and the time of 800 -meter freestyle swimming ," scientific production in the Scientific Arab Conference , the advancement of the Arabic sport, Egypt Expo \& Convention Authority (EECA), the Arab Games tournament, Egypt, 2007

11. Awees Ali Gebaly: Athletic Training, Theory and Practice, First Edition, Dar GMS, Cairo 2000 AD

12. Fatma Ali Azab : modern motor expression , Alexandria, Dar Al-Fikr Al-Arabi 1993 AD

13. Fatima Mohammed Fulayfel : "The impact of educational program by using the Hyper media to learn the basketball skills to the pupils of the second stage of the primary education ," unpublished Ph.D. thesis , Faculty of Physical Education, Minia University, 2003

14. Kamal Mahrous Bayoumi : "The impact of the use of certain means of special strength training inside the water on some of the associated mechanical variables with Front Crawl style ", unpublished Ph.D. thesis, Faculty of Physical Education for Boys, Alexandria University, 1999

15. Mohammed Ibrahim Shehata: A Guide to Modern Gymnastics, second edition, Dar El-Maraaf, Alexandria, 1992

16. Mohammed Ahmed Abdul Ghani Yusuf: "The impact of the use of specific exercises to improve the performance of the side swings on the Mushroom apparatus for the Gymnastics juniors, Unpublished MA Thesis, Faculty of Physical Education for Boys, Alexandria University, 2005

17. Mohammad Hassan Alawy: Athletic Training Science, $13^{\text {th }}$ Edition, Dar El-Maraaf, Cairo, 1994 $\mathrm{AD}$

18. Mohammad Hassan Alawy, Abou El Ela Abdel Fattah: Physiology of Athletic Training, Dar AlFikr Al Arabi, Cairo, 1984 AD

19. Mohammad Hassan Alawy, Mohamed Nasr El Din Radwan: Tests of the motor performance, Cairo, Dar Al-Fikr Al Arabi 2001 AD
20. Mohamed Sobhy Hassanein: bodily patterns of the Champions athletes of both sexes, Cairo, Dar AlFikr Al Arabi 1995 AD

21. Mohamed Mohamed Abdel Aziz, Mohammed Abbas Hassan Dahi, Heba Abdel Azim Hassan: the basics of gymnastics, unpublished Research Note, Faculty of Physical Education, Assiut University, 2009

22. Mohamed Mahmoud Abdel Dayem, Mr. Medhat Saleh, Tariq Mohammed Shoukry: training programs for physical preparation and weight lifting training, Nile Corniche $\mathrm{Al}$ Ahram Press, Cairo, 1993 AD

23. Mohamed Mahmoud Abdel-Salam: the technical performance and the educational steps for the pommel horse and the Parallel exercises, Dar ElMaraaf, Alexandria, 1978

24. Mokhtar Salem: technology of sportive preparation, Dar El-Maraaf for printing and publishing, Beirut, Lebanon, First Edition, 1990 $\mathrm{AD}$

25. Nadia Demerdash, Ekhlas Noureddine, Ferial Abdel-Aziz: flexibility of the thigh and strength of the abdomen and the legs muscles and their relationship to the ability to remain in the lifted position, scientific production in Physical Education newspaper, Helwan University, 1987

\section{Foreign references}

26. Christins Cunningham: The Importance of Functional Strength Training Rersonal Fitness Professional magazine, American Council on Exercise Publication-April 2000

27. Cress ME., Conley, KF., Balding SL, HansenSmith F, Konczak J,: Functional training : muscle structure, Function, and performance in older secomen, J Orthop Sports phys Ther-Jul, 24 (1) : PP4-10 199616

28. 28- Cymara P.K, David E.K, Chris A.M and Donna M.S.: Chair rise and Lifting Characteristic of elders stretching knee Arthritis : Functional training and strengthening effects, J American Physical Therapy Association Vol. 83. N.1. January2004

29. Dave Schmitz : Functional Training Pyramids, Nesec Truer High School, Kinetic Wellness Department, USA. 2003

30. Fabio comana .: Function training for Sports, Human Kinetics : Champaign IL., England 200416

31. Marjkej, Michael F,Bianca R: Anon-cooperative Foundation of Core-Stability in Positive Externality NTU-Coalition Games University of Hagen, Sseceden, 2004

32. Maryg Reynolds What Makes Functional Training? National Strength and Conditioning Association Vol.27.N.1, pp 50 - 55:2003

33. legs's Artistic Gymnastics : International Gymnastics Federation Code of Points. SSECITZERLAND NESEC VERSION, 2009 2010 
34. Michael Boyle: Functional Balance Training Using Domed Device-Spine. Vol. 21 - pp 2640 -

35. Norris, CM.: Abdominal Muscle training in Sport. Journal Article, (I augh borough. Eng.) 27(1). Mar. 1993

36. O-Sullivan, P.B. et al: Altered abdominal muscle recruitment in patients stretching chranic back pain following a specific exerctse mtervention Journal Article. (Baltmore. Md.) 27 (2) : Feb. 1998

37. Ozmum, D.C., Mkesky, A.F., and Surbury, D.R. Neuromus cular adaptation following prepuce escent training Medicine and science in sport and exercise, India Poles, 26, pp : 510-514. 2000

38. Plamondon, A, et al: Tosecard a better prescription of the prone back extension exercise to strength en the back muscles, Journal Article. (Copenhagen) 9 (4). Aug. 1999

39. Stricevic, M.V. et al: Specificity of Karate training comparative an a Lysis of the isodynamic evaluation of a bdominal and back muscles, Book, Analytic. Tenenbaum. G. (ed) and Eiger, D. (ed). 1991

40. Yasumura ST, Hamamura A, : Ishikaseca M, Ito H, Ueda Y, Takehara M, Miyaoka H, Murai C, Murakami S, Moriyama M, Yamamoto K, Yoshinaga T, Takeuchi T, : Characteristics of 2000. 
